University of Wollongong

Research Online

Faculty of Engineering and Information

Faculty of Engineering and Information

Sciences - Papers: Part A

Sciences

$1-1-2013$

\title{
A literature review on business process management, business process reengineering, and business process innovation
}

\author{
Abhijith Anand \\ University of Wollongong, aas188@uowmail.edu.au \\ Samuel Fosso Wamba \\ Rouen Business School, samuel.fosso.wamba@neoma-bs.fr \\ Denis Gnanzou \\ Groupe Sup de Co La Rochelle
}

Follow this and additional works at: https://ro.uow.edu.au/eispapers

Part of the Engineering Commons, and the Science and Technology Studies Commons

Research Online is the open access institutional repository for the University of Wollongong. For further information contact the UOW Library: research-pubs@uow.edu.au 


\title{
A literature review on business process management, business process reengineering, and business process innovation
}

\author{
Abstract \\ Business process management (BPM), business process reengineering (BPR), and business process \\ innovation (BPI) have been the primary strategies adopted by several organizations to manage their \\ business successfully along with IT. In the last few years, the concept of BPM, BPR, and BPI has been a \\ hot topic among the IS community, which is evident in the degree of literatures devoted to it. Due to the \\ dynamic nature of this research area, this paper aims to add knowledge to the existing ones by answering \\ (1) what is the current level of development on BPM, BPR, and BPI within AIS basket of top journals and \\ Science Direct database? and (2) what are the potential future research directions on BPM, BPR, and BPI?. \\ A total of 55 articles from the AIS basket of top journals and 61 articles from the Science Direct database \\ are analyzed based on the year of publications, AIS geographical regions, approaches adopted by the \\ author/s, components of BPM areas and industrial application covered, and potential future research \\ directions are discussed.

\section{Keywords} \\ reengineering, innovation, process, business, management, review, literature \\ Disciplines \\ Engineering | Science and Technology Studies

\section{Publication Details} \\ Anand, A., Fosso Wamba, S. \& Gnanzou, D. (2013). A literature review on business process management, \\ business process reengineering, and business process innovation. In J. Barjis, A. Gupta \& A. Meshkat \\ (Eds.), 9th International Workshop on Enterprise and Organizational Modeling and Simulation (EOMAS) \\ Held at International Conference on Advanced Information Systems Engineering (CAiSE) (pp. 1-23). \\ Heidelberger Platz 3, D-14197 Berlin, Germany: Springer-Verlag Berlin.
}




\title{
A Literature Review on Business Process Management, Business Process Reengineering, and Business Process Innovation
}

\author{
Abhijith Anand ${ }^{1}$, Samuel Fosso Wamba ${ }^{2}$ and Denis Gnanzou ${ }^{3}$ \\ ${ }^{1,2}$ School of Information Systems \& Technology \\ Faculty of Informatics \\ University of Wollongong, Australia \\ aas188@uowmail.edu.au,samuel@uow.edu.au \\ ${ }^{2}$ Rouen Business School, Rouen, France \\ ${ }^{3}$ Groupe Sup de Co La Rochelle, France
}

\begin{abstract}
Business process management (BPM), business process reengineering (BPR), and business process innovation (BPI) have been the primary strategies adopted by several organizations to manage their business successfully along with IT. In the last few years, the concept of BPM, BPR, and BPI has been a hot topic among the IS community, which is evident in the degree of literatures devoted to it. Due to the dynamic nature of this research area, this paper aims to add knowledge to the existing ones by answering (1) what is the current level of development on BPM, BPR, and BPI within AIS basket of top journals and Science Direct database? and (2) what are the potential future research directions on BPM, BPR, and BPI?. A total of 55 articles from the AIS basket of top journals and 61 articles from the Science Direct database are analyzed based on the year of publications, AIS geographical regions, approaches adopted by the author/s, components of BPM areas and industrial application covered, and potential future research directions are discussed.
\end{abstract}

Keywords: Business process, reengineering, innovation, management, literature review.

\section{Introduction}

In the world of emerging technological advancement, penetration of information technology (IT) into the organizations is rapidly increasing. Adoption of IT in core organizational processes is becoming inextricably interwoven in performing everyday activities. Organizations have realized the importance of technology and the role it can play for improving the efficiency and quality of their business processes through effective business process management (BPM). While BPM helps organizations to continuously improve their processes, it also monitors the technological advancements that can be integrated in the development of efficient processes through business process reengineering (BPR) and business process innovation (BPI) [1]. Hence, organizations are continuously redefining their business by means of IT, clearly showing that IT is acting as a tool/catalyst for BPR and BPI [2-5]. Further many empirical research have found a positive correlation between the success of the organization and management of process $[6,7]$.

With the above context, awareness of BPM, BPR, and BPI is expected to be largely known and has also been a popular concept. The purpose of this paper is to review a series of literatures on BPM, BPR, and BPI, which have been published between 2005 and 2011 to accumulate the knowledge and the current development in this area in order to provide possible future directions. Moreover, to the best of our knowledge, there has not been a review paper dealing within the AIS basket of top journals, as these journals are considered top in IS area in the IS field [8]. Hence for this reason, this paper deals with the analysis of literatures both in the AIS basket of top journals and in the Science Direct database.

It is expected that the findings from this paper will emphasize and clearly distinguish the current development of BPM, BPR, and BPI besides its application, approach, and other attributes and contribute towards future research for both academics and practitioners by answering the following questions: 
1. What is the current level of development on BPM, BPR, and BPI within the AIS basket of top journals and the Science Direct database?

2. What are the potential future research directions on BPM, BPR, and BPI?

The remainder of this paper is structured as follows. The next section presents and overview of BPM, BPR and BPI, followed by the research methodology, classification of findings along with results and discussion. Finally, the last section provides the conclusion including limitations and future research directions.

\section{Motivation}

\subsection{Business Process: A Definition}

Business process can be defined as "a collection of activities that takes one or more kinds of input and creates an output that is of value to the customer" [9], or "a specific ordering of activities across time and place, with a beginning and an end with clearly defined inputs and outputs" [10]. Process contains a set of attributes and principled flow of steps in order to achieve a task. In general, process helps in governing the operations of an organization such that it can produce valuable outputs.

Business processes within the organizational context can be divided into (a) operational processes, activities involving a firm's value chain and (b) management process, which consists of information processing, control, coordination and communication governing the overall operation of a system [11].

An organized and controlled flow of operational and management process acts as a core element for the efficient functioning of an organization. Improving the efficiency of the organization directly relates to improving the core business processes. Kohli and Sherer[12] articulate that a process view approach can determine additional factors affecting the conversion of IT assets to successful or unsuccessful impact more clearly at a process level. For example, if an organization decides to improve its efficiency to gain investments and implements IT to achieve the said, then the business value of IT is recognized if it has indeed led to higher efficiency in the organization. Hence, it is eligible to say that analyzing the business process of an organization will gain better results to analyze the impact of IT by identifying the IT mechanisms which add value and understand the relationship between IT and the organization.

Rapid improvements and innovation in IT have led to a competitive environment that organizations are facing today. The impact of IT on organizations has drastically changed over the past decade from supporting roles to building and shaping new strategies to uphold the business goals. Organizations seek to be more agile to the developments of IT such that it can be implemented to produce better services to its customers. It is found that almost $46 \%$ of all capital investment in the US economy is being made in improvement of organizational efficiency through IT [13]. As we see, organizations look to get better business value utilizing IT, as IT continues to penetrate and impact the operational and management process of the organizations, and the business value of IT has also increased simultaneously. This prospective is improved by redesigning the processes in organizations which often results in betterment of organizational structures, thus resulting in enhanced services and efficiency provided to the organizations [11]. Hence, organizations are continuously redefining business value by means of using IT, clearly showing that IT is acting as a tool/catalyst for BPR and BPI.

\subsection{Evolution of business process management, business process reengineering and business process innovation}

\section{Business Process Management}

The origin of BPM dates back to the 1990s where BPM was considered as the next big thing after the workflow wave. Today it evolutes into many concepts including workflow management (WFM), case handling $(\mathrm{CH})$, enterprise application integration (EAI), enterprise resource planning (ERP), customer relation management (CRM) etc. [14].The definitions (Table 1) of BPM in the various extant literatures incorporate a broader view of managing business process in the organisation, utilizing technologies and techniques as tools. Some of the available literatures have built their definitions on technological assessment and the capabilities of changing 
existing business processes. Others define the concept as the synergetic effects created from the combination of technology and human aspects to redefine existing methods.

Therefore BPM can be broadly depicted as a provider of tools and techniques to efficiently manage business processes [15]. BPM can play a crucial part in the development of an organization, especially which focuses on a business process view [1] because BPM not only provides discovery, design, deployment and execution of business processes, but due to the fastidious evolution it can also provide interaction, control, analysis and optimization of processes [16]. Today as the complexity of business process is increasing, organizations are becoming more open and distributed. To help deal with the complexities and adopt with new environments, it has become an obligation for organizations to focus on BPM [17].

Table 1. Definitions of BPM, BPR and BPI

\begin{tabular}{|c|c|c|}
\hline & Definitions & References \\
\hline \multirow[t]{3}{*}{ BPM } & $\begin{array}{l}\text { "a collection of technologies capable of translating business process models into } \\
\text { computer-supported activities, relinquishing routine management and control tasks from } \\
\text { the organizational agents", }\end{array}$ & [18] \\
\hline & $\begin{array}{l}\text { "system which supports business processes using methods, techniques, and software to } \\
\text { design, enact, control and analyze operational processes involving humans, organization, } \\
\text { applications, documents and other sources of information", }\end{array}$ & [19] \\
\hline & $\begin{array}{l}\text { "The modelling, execution (including automation), and evaluation of processes is known } \\
\text { as business process management" }\end{array}$ & {$[20]$} \\
\hline \multirow[t]{5}{*}{ BPR } & $\begin{array}{l}\text { "fundamental rethinking and radical redesign of business processes to achieve dramatic } \\
\text { improvements in critical, contemporary measures of performance, such as cost, quality, } \\
\text { service, and speed". }\end{array}$ & [9] \\
\hline & $\begin{array}{l}\text { "(BPR) is defined as a radical redesign of processes in order to gain significant } \\
\text { improvements in cost, quality, and service", }\end{array}$ & {$[21]$} \\
\hline & $\begin{array}{l}\text { "methodologies to change their internal business processes in response to environmental } \\
\text { change requirements or internal needs", }\end{array}$ & [22] \\
\hline & $\begin{array}{l}\text { "an approach used to create a computer-based system for the management of the supply } \\
\text { chain traceability information flows", }\end{array}$ & [23] \\
\hline & $\begin{array}{l}\text { "Information system development can often be addressed as a business process } \\
\text { reengineering practice, either because it automates some human-based processes or } \\
\text { because it replaces an existing legacy system", }\end{array}$ & {$[24]$} \\
\hline \multirow[t]{3}{*}{ BPI } & $\begin{array}{l}\text { "performing work activities in a radically new way to attain visible and dramatic results } \\
\text { to meet the business objectives", }\end{array}$ & [10] \\
\hline & $\begin{array}{l}\text { "end-to-end process by which improved, renewed, or replacement products, } \\
\text { solutions, and services are delivered in practice, generating } \\
\text { new "top line" business value" }\end{array}$ & {$[25]$} \\
\hline & "[Achieving] an entirely new set of performance features" & [26] \\
\hline
\end{tabular}

\section{Business Process Reengineering}

It all began in the 1990s when Michael Hammer, father of reengineering, published the article "Reengineering work: don't automate, obliterate" in the Harvard Business Review. The improved results from the article were dramatic for many organizations that it became a trend during 1994 [27]. Success stories such as 'Ford cuts accounts payable headcount by 75\%', 'Mutual Benefit Life improves insurance underwriting efficiency by $40 \%$ ' [28], 'Xerox redesigns its order fulfilment process and improves service levels by $75 \%$ to $97 \%$ and cycle times by $70 \%$ with inventory savings of $\$ 500$ million'; 'Detroit Edison reduces payment cycles for work orders by $80 \%$ ' still shine like beacons [29].The classic definition for business process reengineering is given by Hammer and Champy[9] (See Table 1).

As we can see, definitions (Table 1) have been evolving with time from more than one process perspective to the technological aspects involved in processes. BPR is considered to be an old technique for reinventing business processes. Re-inventing has been primarily dependent on management wisdom, creativity 
and common sense in changing management. Hence, by definition, BPR supports scrapping the entire business process to build entirely new processes. Formulating definitions is easier, but achieving the same in practical terms is a different task. In contrast, as the definitions have evolved, researches seem to incorporate technological aspects to support the reinventions of business processes[25]. These definitions hold a valid meaning to some extent, because present day organizations are facing ever increasing challenges to acclimatize their services to relentless changes in technology, politics and surrounding environments. It is becoming mandatory to improve the quality of services they are providing [30] to stay firmly in the market. In addition, organizations are no longer able to cope with the traditional management mechanisms to satisfy their clients. Moreover, customers, competition and change have made them enter into the intense environment with excessive demands where mass productivity and quality of services with short turnaround time is necessary [31]. To meet such demands, organizations cannot rely on IT alone to meet the firm's goals, as they also need to look into their core processes to meet the changes needed. The basic foundation of BPR is in redesigning the processes, especially the one which helps in developing business value of the organization, and IT is used as a mere tool which helps in automating processes [31]. Hence, with BPR, organizations are able to analyze the fundamental business processes and systems, restructure them periodically such that they can be flexible to future redesigns.

\section{Business Process Innovation}

The best definition of the term "innovation" comes from Joseph Schumpeter [32] who defined innovation as (i) a new way of handling processes, (ii) a new product unknown to clients, (iii) new markets previously not known, (iv) new sources of supplies, and (v) new competitive structure in an organization. Rogers [33] defines innovation as any idea, practice or object that is perceived to be new by an individual or other units of adoption.

Damanpour [34] points out that there are two types of innovations: technical innovations, and administrative innovations. Technical innovations deal with realizing new processes, products or services, whereas administrative innovations are implementing new procedures, policies and organizational forms [3537].

In the modern marketplace where technology, globalization, awareness and continuous improvisation decide the overall performances of the organizations [38], it is to be understood that the environment is also becoming more dynamic, complex and unpredictable [39] for the organizations. Organizations are seeking new ways of conducting business, such as stable finance, customer satisfaction and gain competitive edge in the market by responding quickly, to deliver services and products in view of greater returns (organizational learning) [36, 40-44], and especially in the last decade, innovation has been the key to achieve the above. Studies on innovation suggest that organizations tend to achieve better resource management, improved quality, creativity, performance, strategic planning, cost and time reductions, and administrative controls, resulting in longer survival of organizations [11, 45-49]. Though innovation is quite complex and hard to achieve for every organization, studies show that organizations are looking towards IT to achieve process innovation and process reengineering to get the greater value $[10,50]$. Process innovation is consequently linked with process reengineering because process innovation is creating a new way of handling a process and process reengineering is about achieving that new process innovation. As mentioned earlier, IT is the enabler for process innovation, and process innovation initiates process reengineering, thus showing that IT has a vital role to play in the reengineering process while positioning itself as a key enabler of innovating processes (operational and management).

In the above context, process innovation can be perceived as a method to align resources such as IT with the business strategies of organizations. To attain a significant business value from IT depends on its relationship with process reengineering. Since process reengineering is where innovations are put into the right place with the applications of IT and to a degree where IT might ultimately facilitate automating the processes. Given that IT is considered as a source for process innovation, while process innovation is considered to be the catalyst for understanding the business value of IT [11], it is important for organizations to focus on process innovation before process reengineering and process management to realize their business strategies through IT. 


\section{Research Methodology}

In order to answer the above questions, a series of literatures that are published between 2005 and 2011 are examined. The reason behind choosing only the last few years is that even though the concept of BPM, BPR, and BPI has been present for more than a decade and has been continuously redefined, examining the last few years allows us to track the latest developments residing with BPM, BPR, and BPI. Furthermore, to achieve the studies intended, all the literature that are examined are related to BPM, BPR, and BPI and their applications. The literature search was carried out within the journals proposed by the AIS senior scholars, namely European Journal of Information Systems (EJIS), Information Systems Journal (ISJ), Information Systems Research (ISR), Journal of AIS (JAIS), Journal of MIS (JMIS), and MIS Quarterly (MISQ) along with the two additional journals suggested by them, Journal of Strategic Information Systems (JSIS) and the Journal of Information Technology (JIT) for an overall of eight journals. Similarly, literature search was also carried out in the Science Direct database as one of the largest, widely recognized databases in Business Administration, Social Science, and Technology. Analysing the AIS basket of top journals and Science Direct database will enable us to examine the extent core management of information fields devoted to the concepts of BPM, BPR and BPI compared to other fields of research. Only peer-reviewed literatures were retained as it is believed that journals are commonly used resources to obtain information and publish new findings [51].

Literatures were searched based on the descriptors "Business Process Management," "Business Process Reengineering," "Business Process Innovation," "BPM,'”BPR," and "BPI." We obtained 96 articles from the AIS journal list and 111 articles from the Science Direct database. After a careful review of each article by and from each of co-authors of the present paper, 41 articles from the AIS journal list and 50 articles from the Science Direct database were removed from the study on grounds that they did not fit our objectives. For the final review, a total of 55 articles from AIS journals and 61 from Science Direct database were retained for further in-depth analysis and classification. The selected 116 articles were reviewed, one article at a time, by the co-author in order to assess their fitness for classification. In case of ambiguity, verification was conducted by two co-authors to reach consensus. All the classification frameworks were verified by the one co-author for consistency.

\begin{tabular}{|c|c|c|c|c|c|c|c|c|c|}
\hline Journals & 2005 & 2006 & 2007 & 2008 & 2009 & 2010 & 2011 & Journals Total & $\%$ \\
\hline EJIS & 11 & 5 & 1 & 4 & 2 & 7 & 0 & 30 & 54.5 \\
\hline$I S J$ & & & & & & & & - & - \\
\hline ISR & & 2 & & & 1 & & & 3 & 5.4 \\
\hline$J I T$ & 3 & 1 & 3 & 2 & 5 & 4 & 0 & 18 & 32.7 \\
\hline$J M I S$ & & & & & & & & - & - \\
\hline$J S I S$ & & & & & & & & - & - \\
\hline$J A I S$ & & & & & & & & - & - \\
\hline MISQ & 4 & & & & & & & 4 & 7.2 \\
\hline AIS basket of top journals - Total & 18 & 8 & 4 & 6 & 8 & 11 & 0 & 55 & \\
\hline$\%$ & 32.7 & 14.5 & 7.2 & 11 & 14.5 & 20 & 0 & & 100 \\
\hline Science Direct database - Total & 6 & 12 & 10 & 10 & 7 & 5 & 11 & 61 & 100 \\
\hline$\%$ & 9.8 & 19.6 & 16.3 & 16.3 & 11.4 & 8.1 & 18 & & 100 \\
\hline Grand Total & 24 & 20 & 14 & 16 & 15 & 16 & 11 & 116 & \\
\hline
\end{tabular}

\subsection{Classifications, Results, and Discussions}

Table 2 presents the classification of articles based on the year of publication. It is surprising to see that four (ISJ, JMIS, JSIS, and JAIS) out of eight AIS journals have no relevant publication or discussions toward BPM, BPR, and BPI even after a lot of significance it has been under. In addition, journals like ISR (three articles, 5.4\%) and MISQ (four articles, 7.2\%) have showed little affinity toward the subject. In contrast, EJIS (30 articles, 54.5\%) and JIT (18 articles, 32.7\%) have showed a lot of prominence toward the subjects of BPM, BPR, and BPI.

Most of the articles were published in the year 2005 (18 articles, 32.7\%), followed by a mild fall and rise from 2006 (8 articles, 14.5\%) to 2010 (11 articles, 20\%), and an unexpectedly no articles in the year 2011 from 
none of the AIS journals. On the other hand, articles from the Science Direct database have been consistent with the publication of articles in all the years considered. The highest publication has come in the year 2006 (12 articles, 19.6\%) and 2011 (11 articles, 18\%) with little variations in between. Overall, it is important to notice that the publications on BPM, BPR, and BPI have been declined, taken from any point of view, AIS basket of top journals, or even overall as shown in Figure 1.

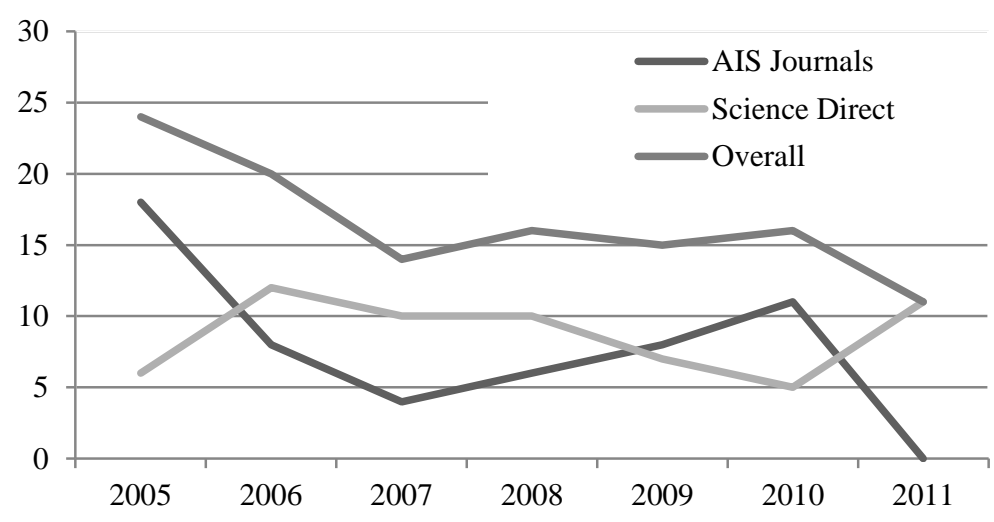

Figure 1.Trend analysis of publications

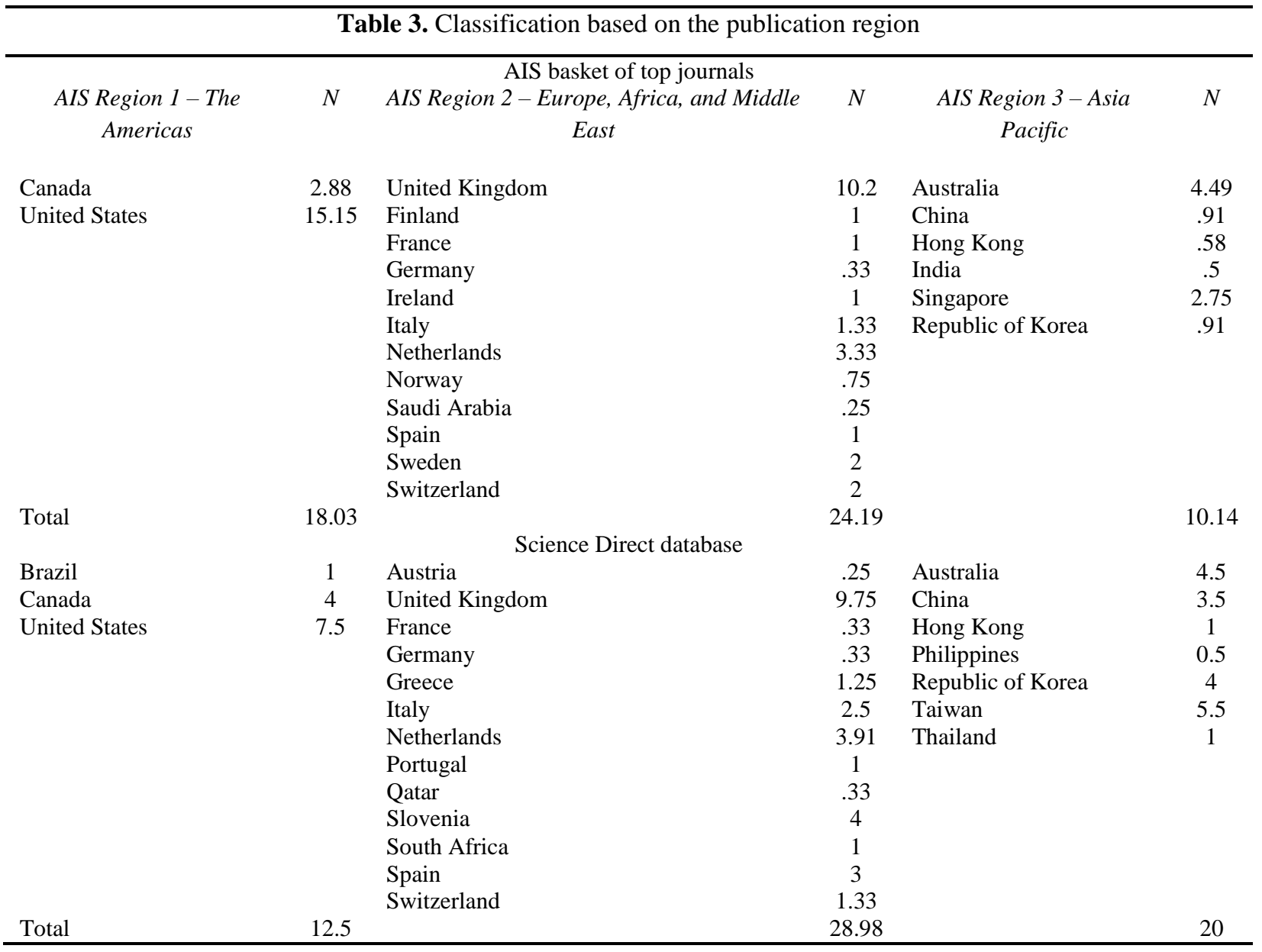

Table 3 summarizes the number of articles contributed by the author/s in terms of different geographical areas. This gives us an overview on the origins of the papers submitted and published over the past seven years. $N$ corresponds to the number of the university or other organization the author/s was/were working at the time of publication. A count was performed on the number of times each article made a contribution from its geographical location. In order to be more specific in our analysis without any distinction of bias, if the articles were published 
in multiple places (or if they have multiple authors), it was resolved by the simple following method: $x=\mathrm{y} \div$ $\mathrm{z}$, where $x=$ the value for the geographical area, $y=$ the number of articles ( 1 by default), and $z=$ places of publications. This greatly enhances the accuracy of the results when compared to simply counting the same value. Further, the geographical areas were classified based on the AIS regions [52, 53].

The findings from Table 3 illustrate that most of the publications for the AIS journals have come from region $2(N=24.19)$, with the United Kingdom being the highest contributor $(N=10.2)$ for that region, followed by region $1(N=18.03)$ and region $3(N=10.14)$. The results obtained are similar to those by Dwivedi and Kuljis [52] in their research on information systems. A clear domination of the United States can be observed as being the highest contributor $(N=15.15)$ among all the contributors of AIS regions, even though the AIS region 1 in which the United States is categorized is second after region 2.

On the other hand, results from the Science Direct database vary slightly; contributions from region $2(N$ $=28.98$ ) have been dominated here also, with United Kingdom again being the top contributor for that region. But, region 3 has dominated $(N=20)$ over region $1(N=12.5)$ geographical area. Furthermore, even though region 1 lasts, it has to be noted that the United States $(N=7.5)$ is again among the highest contributor, just behind the United Kingdom.

\begin{tabular}{|c|c|c|c|c|}
\hline Approaches & $\begin{array}{c}\text { AIS Journals } \\
\text { Number of Articles }\end{array}$ & $\%$ & $\begin{array}{c}\text { Science Direct } \\
\text { Number of Articles }\end{array}$ & $\%$ \\
\hline Conceptual & 4 & 6.3 & 13 & 16.2 \\
\hline Review & 3 & 4.7 & 4 & 5 \\
\hline Data Analysis & 5 & 7.9 & 1 & 1.2 \\
\hline Survey & 11 & 17.4 & 16 & 20 \\
\hline Experiment & 4 & 6.3 & 10 & 12.5 \\
\hline Case Study & 30 & 47.6 & 27 & 33.7 \\
\hline Developmental & 1 & 1.5 & 9 & 11.25 \\
\hline $\begin{array}{l}\text { Others (Ethnography, } \\
\text { Action Research) }\end{array}$ & 5 & 7.9 & - & - \\
\hline Total $*$ & 63 & 100 & 80 & 100 \\
\hline
\end{tabular}

Table 4 summarizes the classification of articles based on the approach adopted by the authors. The results from Table 4 evidently show that case studies (30 articles, 47.6\% from AIS journals and 27 articles, 33.7\% from Science Direct) were the most common approach adopted by the authors of both the sources. It is indeed even though BPM, BPR, and BPI have been for a long time, factors such as ever-changing economy, dynamic organizational changes, and IT have made the subjects evolve in a rapid pace in the recent years, and most of the concepts remain largely theoretical $[53,54]$. In this context, it can be said that it is appropriate to adopt the case study approach in the study of the new or evolving concepts as it allows to induce theories from it [55, 56]. Similarly, survey studies (11 articles, 17.4\% from AIS journals and 16 articles, 20\% from Science Direct) are the second-most approach adopted by the authors from both the sources. Other approaches were also fairly used in the articles from Science Direct such as conceptual (13 articles, 16.2\%) and experiment (10 articles, 12.5\%), but it was not seen from the AIS basket of top journals. It can also been observed there is not much of review analysis done in the recent years, which is evident in both AIS journals (three articles) and Science Direct database (four articles).

In order to capture the topics covered in the reviewed articles, it is important to capture the attributes in four important views - the people view, the process view, the resource view, and the customer view. The critical success factor for implementing and sustaining BPM in the organisation depends on its ability to understand the changes and effects across all four dimension [57]. The people view typically comprises components including organisational structures, culture, roles, responsibilities, accountabilities, competencies, jobs and communication. The process view comprises elements such as the way of planning, control and changes in business processes. The resource view spotlights on resources used within an organisation and the way organisations integrate resources into business process to their respective performances and utilisation levels. Finally, the customer view deals through the requirements in a customer's perspective such as customer segments, service characteristics and design in addition to customer feedback. Therefore, we have adopted a framework proposed by Antonie van Rensburg [57], shown in Table 5, which contains the critical component of the BPM in order to achieve a successful process-based organization. 
Table 5. Business Process Components

\begin{tabular}{|c|c|c|}
\hline Covered Topics & Goals & Objectives \\
\hline Customer Management & $\begin{array}{l}\text { Integrate and focus value delivery on } \\
\text { the customer }\end{array}$ & $\begin{array}{l}\text { Identify needs/wants } \\
\text { Develop product /service profile } \\
\text { Obtain constant customer satisfaction feedback }\end{array}$ \\
\hline Planning & $\begin{array}{l}\text { Plan value and the delivery of value } \\
\text { thereof to the customer }\end{array}$ & $\begin{array}{l}\text { Establish goals (policies) } \\
\text { Define capabilities } \\
\text { Develop product /service features }\end{array}$ \\
\hline Control & $\begin{array}{l}\text { Establish measures for operational } \\
\text { performance }\end{array}$ & $\begin{array}{l}\text { Define standards } \\
\text { Define measurements }\end{array}$ \\
\hline Resource Management & $\begin{array}{l}\text { Manage operational activities of the } \\
\text { organization }\end{array}$ & $\begin{array}{l}\text { Obtain performance levels } \\
\text { Measure deviations }\end{array}$ \\
\hline Knowledge Management & Grow organization knowledge & $\begin{array}{l}\text { Create knowledge } \\
\text { In-source plans, controls, and solutions }\end{array}$ \\
\hline Change Process & $\begin{array}{l}\text { Change the organization in order to } \\
\text { meet customer requirements }\end{array}$ & $\begin{array}{l}\text { Develop solutions through innovation } \\
\text { Re-establish control } \\
\text { Support managing the "resistance to change" }\end{array}$ \\
\hline Learning & Convert knowledge into innovation & Create innovation \\
\hline People & $\begin{array}{l}\text { Enable people in a changing } \\
\text { environment }\end{array}$ & $\begin{array}{l}\text { Establish structure } \\
\text { Establish the culture } \\
\text { Establish reward and recognition }\end{array}$ \\
\hline Performance Management & $\begin{array}{l}\text { Evaluate performance of the } \\
\text { organization }\end{array}$ & $\begin{array}{l}\text { Reward and recognize people, Collate relevant } \\
\text { performance levels }\end{array}$ \\
\hline
\end{tabular}

The article reviews were classified based on the coverage of the above components. In order to get a detailed analysis, we capture the frequency of publications covering the above components over the years for both AIS basket of top journal articles and Science Direct database articles. Table 6 summarizes the finding as shown below. It is interesting to see that both AIS journal articles and Science Direct database articles covered topic on knowledge management the most (21 articles, $19.4 \%$ and 18 articles, $15.6 \%$, respectively), followed closely by covering the topic on change process (15 articles, $13.8 \%$ and 17 articles, $14.7 \%$, respectively), performance management (11 articles, $10.1 \%$ and 17 articles, $14.7 \%$, respectively), and control (14 articles, $13 \%$ and 13 articles, $11.3 \%$, respectively). Surprisingly, articles on customer, management (seven articles and nine articles) and resource management (eight articles and 10 articles) resulted in the lowest numbers. Also as mentioned earlier, AIS journal articles did not cover topics regarding BPM, BPR, and BPI in 2011, which seems to be highly noted.

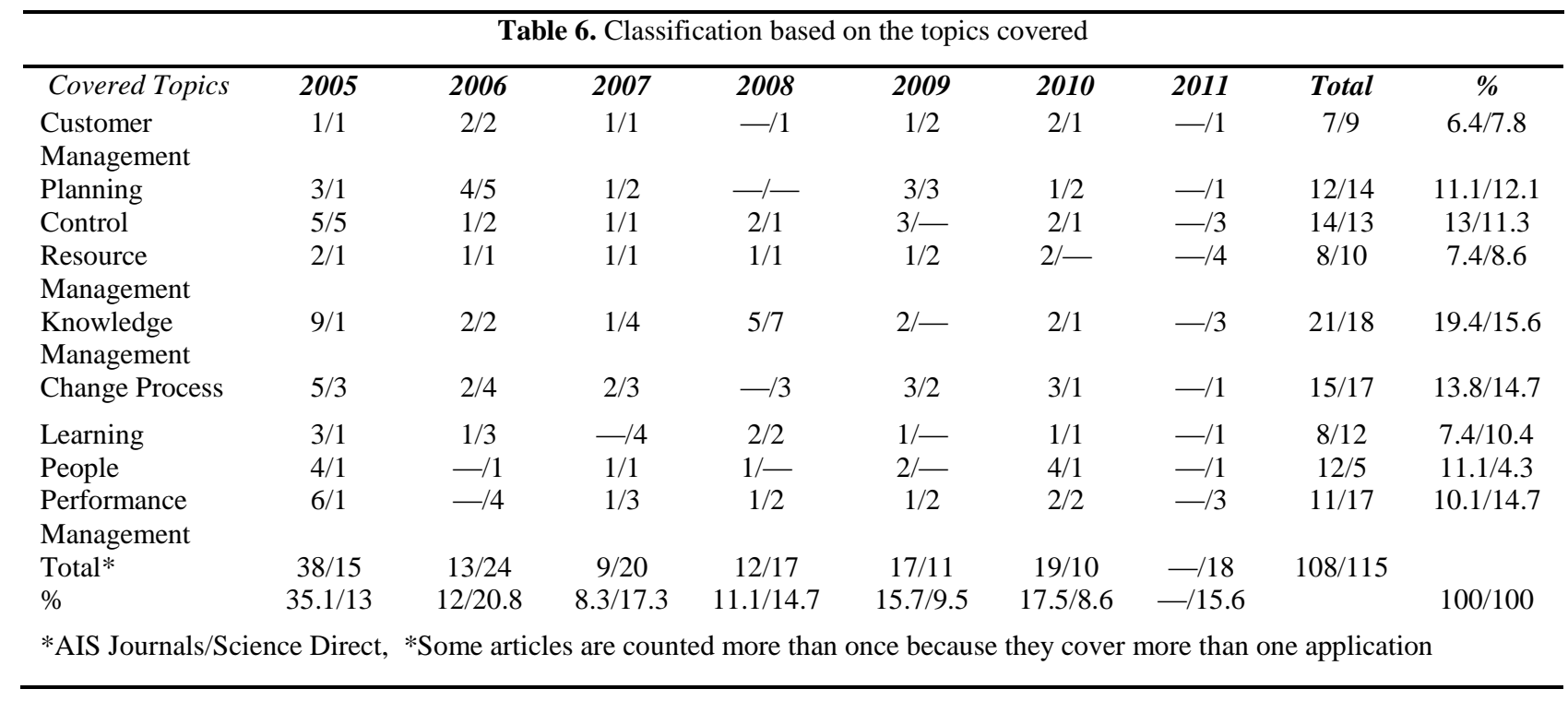




\begin{tabular}{|c|c|c|c|c|}
\hline \multicolumn{5}{|c|}{ Table 7. Classification based on the application area } \\
\hline Application areas & AIS Journals & $\%$ & Science Direct & $\%$ \\
\hline Banking/ & 8 & 11 & 4 & 5.7 \\
\hline Financial & & & & \\
\hline Healthcare & 3 & 4.1 & 6 & 8.5 \\
\hline Government & 8 & 11 & 5 & 7.1 \\
\hline Logistics & 3 & 4.1 & 3 & 4.2 \\
\hline Supple Chain & 2 & 2.7 & 6 & 8.5 \\
\hline$I T$ & 10 & 13.7 & 1 & 1.4 \\
\hline Manufacturing & 8 & 11 & 14 & 20 \\
\hline Paper Industry & 1 & 1.4 & - & - \\
\hline Automotive & 2 & 2.7 & 3 & 4.2 \\
\hline Education & 2 & 2.7 & 2 & 2.8 \\
\hline Retail & 6 & 8.2 & 1 & 1.4 \\
\hline Others & 20 & 27.4 & 25 & 35.7 \\
\hline Total $*$ & 73 & 100 & 70 & 100 \\
\hline
\end{tabular}

The areas of industrial application were identified in the reviewed articles summarized in Table 7. It can be observed that AIS journal articles focused on IT industry the most (10 articles, 13.7\%), followed by application in banking/financial industry, government, and manufacturing (eight articles each, 11\%). The least covered areas of application were paper industry (one article), supply chain, automotive and education (two articles each), and finally healthcare and logistics (three articles each). In contrast, manufacturing (14 articles, 20\%) was the most focused industry in the articles from Science Direct database, followed by healthcare and supply chain (six articles, $8.5 \%$ ). Coverage on paper industry was none; IT and retail (one article each), education (two articles), and logistics ( 3 articles) were on the lower side of application. The application area "others" includes all papers for which we could not identify the specific application area or those which were outside our research focus, etc. (e.g. survey or simulation literature).

\section{Conclusion, Limitations, and Future Directions}

In this paper, a complete analysis of papers related to BPM, BPR, and BPI within the AIS basket of top journals and Science Direct database was presented and discussed. From the obtained results, we saw that even though BPM, BPR and BPI have been there for a long time, AIS top journals do not dedicate themselves significantly to such topics (only a few journals). In fact, there were no articles found in the journals from ISJ, JMIS, JSIS, and JAIS, and journals like ISR and MISQ had extremely few articles. The only journals that stood out from the AIS basket of top journals were EJIS (30 articles) and JIT (18 articles); they also had consistent publications on the topics over the years. The review from Science Direct database gave us a glimpse of the "other" side of journals. The results obtained were consistent throughout the years with small variations. It would be interesting to see if the scope of this research could be extended to databases such as Web of Knowledge, ABI Inform and more technical libraries such as ACM Digital Library, Elsevier (SCOPUS) and IEEE Xplore, while focusing on the critical success factors dealing with the BPM, BPR, and BPI. This enables us to understand the success and failure rates and attempt to overcome the "theoretically grounded" elements surrounding BPM, BPR, and BPI. Publications in ISJ, JMIS, JSIS, and JAIS on BPM, BPR, and BPI should also be quickly developed (like organizing special editorial issues). Indeed, this can enable a more profound and sophisticated analysis of BPM, BPR, and BPI within the AIS basket of top journals; in parallel, the downslide of publications within the AIS basket of top journals may be avoided.

Reflecting back on the findings from this paper, it is possible to lay a path for future research. Publications from AIS region 3 (Asia-Pacific) in the articles from Science Direct database were considerably high, when compared to publications from AIS journals (region 3). It is worthy to mention if the concentration of the current research is aimed toward AIS basket of top journals; it could balance the values on both sides. Concerning the authors' approaches, only few papers were found to have tackled the topics of developmental and data analysis, and reviewed approaches on BPM, BPR, and BPI. Clearly, more studies are needed to increase the quantity of evidence for such approaches. Similarly, articles on customer management (16 articles in total) and resource management also resulted in the numbers (18 articles in total); this is also one of those areas of research which has to be highly looked into as BPM, BPR, and BPI have high affinity toward these areas. Also, studies dealing with industry application areas, such as supply chain, automotive, logistics and healthcare, should be 
carried court, as such industries and especially the healthcare sector are undergoing a good deal of changes. Future research with classification frameworks based on architectures and models employed may provide deeper insights. Finally, the contributions of this paper can be highlighted in other ways, as it provides the IS community with well-researched and evidence-supported data on BPM, BPR and BPI.

\section{References}

1. Kohlbacher, M., The perceived effects of business process management, in Science and Technology for Humanity (TIC-STH), 2009 IEEE Toronto International Conference. 2009. p. 399-402.

2. Becker, J., R. Fischer, and C. Janiesch, Optimizing U.S. Health Care Processes - A Case Study in Business Process Management. AMCIS 2007 Proceedings. Paper 504, 2007.

3. Becker, J. and C. Janiesch, Restrictions in Process Design: A Case Study on Workflows in Healthcare, in Business Process Management Workshops, A. ter Hofstede, B. Benatallah, and H.-Y. Paik, Editors. 2008, Springer Berlin / Heidelberg. p. 323-334.

4. $\quad$ Framinan, J., et al. Business Process Management techniques for health services: Experiences and Application. in Second World Conference of POM and 15th Annual POM Conference. 2004. Cancun, Mexico.

5. Mariska , N., et al., BPR Best Practices for the Healthcare Domain, in Conference: Business Process Management BPM. 2009: France.

6. Guha, S. and W.J. Kettinger, Business process reengineering. Information Systems Management, 1993. 10(3): p. 1322 .

7. Strnadl, C.F., Aligning business and it: The process-driven architecture model. Information Systems Management, 2006. 23(4): p. 67-77.

8. Myers, M. and F. Liu. What Does the Best IS Research Look Like? An Analysis of the AIS Basket of Top Journals. in Pacific Asia Conference on Information Systems. 2009. Hyderabad, India

9. Hammer, M. and J. Champy, Reengineering the corporation: A manifesto for business revolution. Business Horizons, 1993. 36(5): p. 90-91.

10. Davenport, T.H., Process Innovation Reengineering Work through Information Technology. Harvard Business School Press, 1993.

11. Mooney, J.G., V. Gurbaxani, and K.L. Kraemer, A process oriented framework for assessing the business value of information technology. SIGMIS Database, 1996. 27(2): p. 68-81.

12. Kohli, R. and S. Sherer, "Measuring Payoff of Information Technology Investments: Research Issues and Guidelines,". Communications of the Association for Information Systems, 2002. 9(14): p. 241-268.

13. Devaraj, S. and R. Kohli, Performance Impacts of Information Technology: Is Actual Usage the Missing Link? Management Science, 2003. 49(3): p. 273-289.

14. Weske, M., W.M.P. van der Aalst, and H.M.W. Verbeek, Advances in business process management. Data \& Knowledge Engineering, 2004. 50(1): p. 1-8.

15. Huang, Z., et al., Reinforcement learning based resource allocation in business process management. Data \& Knowledge Engineering, 2011. 70(1): p. 127-145.

16. Smith, H., Business process management--the third wave: business process modelling language (bpml) and its picalculus foundations. Information and Software Technology, 2003. 45(15): p. 1065-1069.

17. Wang, M. and H. Wang, From process logic to business logic--A cognitive approach to business process management. Information \& Management, 2006. 43(2): p. 179-193.

18. Antunes, P. and H. Mourão, Resilient Business Process Management: Framework and services. Expert Systems with Applications, 2011. 38(2): p. 1241-1254.

19. Pyon, C.U., J.Y. Woo, and S.C. Park, Service improvement by business process management using customer complaints in financial service industry. Expert Systems with Applications, 2011. 38(4): p. 3267-3279.

20. zur Muehlen, M. and M. Indulska, Modeling languages for business processes and business rules: A representational analysis. Information Systems, 2010. 35(4): p. 379-390.

21. Ozcelik, Y., Do business process reengineering projects payoff? Evidence from the United States. International Journal of Project Management, 2010. 28(1): p. 7-13.

22. Holland, C.P., D.R. Shaw, and P. Kawalek, BP's multi-enterprise asset management system. Information and Software Technology, 2005. 47(15): p. 999-1007.

23. Bevilacqua, M., F.E. Ciarapica, and G. Giacchetta, Business process reengineering of a supply chain and a traceability system: A case study. Journal of Food Engineering, 2009. 93(1): p. 13-22.

24. Grau, G., X. Franch, and N.A.M. Maiden, PRiM: An $i *$-based process reengineering method for information systems specification. Information and Software Technology, 2008. 50(1-2): p. 76-100.

25. Smith, H., P-TRIZ in the History of Business Process. 2006, BPTrends.

26. Leigh, R., Radical innovation: how mature companies can outsmart upstarts. 2000: Harvard Business School Publishing India Pvt. Limited.

27. Graham, I. and R. Williams, The use of management texts: Hammer's reengineering. Scandinavian Journal of Management, 2005. 21(2): p. 159-175.

28. Hammer, M., Reengineering Work: Don't Automate, Obliterate. Harvard Business Review, 1990. 68(4): p. $104-112$.

29. Grover, V. and M.K. Malhotra, Business process reengineering: A tutorial on the concept, evolution, method, technology and application. Journal of Operations Management, 1997. 15(3): p. 193-213.

30. Tehraninasr, A. and E.H. Darani, Business Process Reengineering: A Holistic Approach, in Information and Financial Engineering, 2009. ICIFE 2009. International Conference on. 2009. p. 79-82.

31. Miao, Y.-j., How Does the Enterprise Implement Business Process Reengineering Management, in E-Business and E-Government (ICEE), 2010 International Conference on. 2010. p. 4100-4102. 
Schumpeter, J.A., The Theory of Economic Development. 1938, Cambridge, MA: Harvard University Press. Rogers, E., Diffusion of Innovations. 1995, New York: Free Press.

Damanpour, F., Organizational innovation: a meta-analysis of effects of determinants and moderators Acad Manage J, 1991. 34(3).

Dewar, R.D.D., Jane E;, The adoption of radical and incremental innovations: an empirical analysis. Management Science, 1986. 32(11): p. 1422-33.

Utterback, J., Mastering the dynamics of innovation: how companies can seize opportunities in the face of technological change. Harvard Business School, 1994.

\section{Tushman, M. and D. Nadler, Organizing for innovation. Calif Manage Rev, 1986. 28(3): p. 74-92.}

Hitt, M.A., et al., Introduction to the special issue-strategic entrepreneurship: Entrepreneurial Strategies for wealth creation. Strategic Management Journal, 2001. 22.

Coopers and Lybrand, How to Innovate with Trust and Passion. 1997, London: Coopers and Lybrand.

Stopford, J., Should strategy makers become dream weavers? Harvard Business Review, 2001. 79(1): p. 165-169.

Baker, W. and J. Sinkula, Market orientation, learning orientation and product innovation: delving into the organization's black box. Market Focus Manage, 2002. 5(1): p. 5-23.

Balkin, D., G. Markaman, and L. Gómez-Mejía, Is CEO pay in high-technology firms related to innovation? Acad Manage J, 2000. 43(6).

Brockmand, B. and F. Morgan, The role of existing knowledge in new product innovativeness and performance. Decision Sciences, 2003. 32(2): p. 385-419.

Gnyawali, D., A. Steward, and J. Grant, Creation and utilization of organizational knowledge: an empirical study of the roles of organizational learning on strategic decision making. Acad Manage Proc, 1997: p. 16-20.

Hitt, M., et al., The market for corporate control and firm innovation. Acad Manage J, 1996. 39: p. 1084-1119.

Banbury, C. and W. Mitchell, The effect of introducing importantincremental innovations on market share and business survival. Strategic Management Journal, 1995. 16: p. 161-182.

Amabile, T.M., et al., Assessing the work environment for creativity. Academy of Management, 1996. 39(11541184).

Dougherty, D. and C. Hardy, Sustained product innovation in large, mature organizations: overcoming innovation-to organization problems. Acad Manage J, 1996. 39(1120): p. 1153.

Davis, B.M., Creativity \& Innovation in Business 2010 Teaching the Application of Design Thinking to Business. Procedia - Social and Behavioral Sciences, 2010. 2(4): p. 6532-6538.

Serrano, A. and M. den Hangst, Modelling the integration of BP and IT using business process simulation. Journal of Enterprise Information Management 2005. 18((5/6)): p. 740-759.

Ngai, E.W.T., et al., RFID research: An academic literature review (1995-2005) and future research directions. International Journal of Production Economics, 2008. 112(2): p. 510-520.

Dwivedi, Y.K. and J. Kuljis, Profile of IS research published in the European Journal of Information Systems. European Journal of Information Systems, 2008. 17(6): p. 678-693.

Karim, J., T. Somers, and A. Bhattacherjee, The Impact of ERP Implementation on Business Process Outcomes: A Factor-Based Study. J. Manage. Inf. Syst., 2007. 24(1): p. 101-134.

\section{39(2): p. 125-134.}

Benbasat, I., D.K. Goldstein, and M. Mead, The case research strategy in studies of information systems. MIS Quarterly, 1987. 11(3): p. 369-386.

Yin, R.K., Case Study Research: Design and Methods. 1994, Newbury Park, CA: Sage. 192.

van Rensburg, A., A framework for business process management. Computers \& Industrial Engineering, 1998. 35(12): p. 217-220.

Duan, C., V. Grover, and N. Balakrishnan, Business Process Outsourcing: an event study on the nature of processes and firm valuation. European Journal of Information Systems, 2009. 18(5): p. 442-457.

Ashurst, C., N.F. Doherty, and J. Peppard, Improving the impact of IT development projects: the benefits realization capability model. European Journal of Information Systems, 2008. 17(4): p. 352-370.

Sun, S.X., J.F. Nunamaker, and O.R. Liu Sheng, Formulating the Data-Flow Perspective for Business Process Management. Information Systems Research, 2006. 17(4): p. 374-391,441.

Dong, S., S.X. Xu, and K.X. Zhu, Information Technology in Supply Chains: The Value of IT-Enabled Resources Under Competition. Information Systems Research, 2009. 20(1): p. 18-32,155,157.

Bernstein, B. and P.J. Singh, An integrated innovation process model based on practices of Australian biotechnology firms. Technovation, 2006. 26(5-6): p. 561-572.

Srivardhana, T. and S.D. Pawlowski, ERP systems as an enabler of sustained business process innovation: A knowledge-based view. The Journal of Strategic Information Systems, 2007. 16(1): p. 51-69.

Raus, M., J. Liu, and A. Kipp, Evaluating IT innovations in a business-to-government context: A framework and its applications. Government Information Quarterly, 2010. 27(2): p. 122-133.

Roper, S., J. Du, and J.H. Love, Modelling the innovation value chain. Research Policy, 2008. 37(6-7): p. 961-977. Lin, Y., et al., Positioning strategic competitiveness of green business innovation capabilities using hybrid method. Expert Syst. Appl., 2011. 38(3): p. 1839-1849.

Koellinger, P., The relationship between technology, innovation, and firm performance--Empirical evidence from ebusiness in Europe. Research Policy, 2008. 37(8): p. 1317-1328.

Cho, C. and S. Lee, A study on process evaluation and selection model for business process management. Expert Systems with Applications, 2011. 38(5): p. 6339-6350.

6. Jung, J., I. Choi, and M. Song, An integration architecture for knowledge management systems and business process management systems. Computers in Industry, 2007. 58(1): p. 21-34.

Reijers, H.A. and S. Liman Mansar, Best practices in business process redesign: an overview and qualitative evaluation of successful redesign heuristics. Omega, 2005. 33(4): p. 283-306. 
71. Klassen, R.D. and L.J. Menor, The process management triangle: An empirical investigation of process trade-offs. Journal of Operations Management, 2007. 25(5): p. 1015-1034.

72. Cheng, M.-Y., H.-C. Tsai, and Y.-Y. Lai, Construction management process reengineering performance measurements. Automation in Construction, 2009. 18(2): p. 183-193.

73. Limam Mansar, S., H.A. Reijers, and F. Ounnar, Development of a decision-making strategy to improve the efficiency of BPR. Expert Systems with Applications, 2009. 36(2, Part 2): p. 3248-3262.

74. Lee, H. and H.-W. Suh, Workflow structuring and reengineering method for design process. Computers \& Industrial Engineering, 2006. 51(4): p. 698-714.

75. Petter, S., W. Delone, and E. McLean, Measuring information systems success: models, dimensions, measures, and interrelationships. European Journal of Information Systems, 2008. 17(3): p. 236-263.

76. Vidgen, R. and X. Wang, From business process management to business process ecosystem. Journal of Information Technology, 2006. 21(4): p. 262-271.

77. Piccoli, G. and B. Ives, Review: IT-Dependent Strategic Initiatives and Sustained Competitive Advantage: A Review and Synthesis of the Literature. MIS Quarterly, 2005. 29(4): p. 747-776.

78. Becheikh, N., R. Landry, and N. Amara, Lessons from innovation empirical studies in the manufacturing sector: A systematic review of the literature from 1993-2003. Technovation, 2006. 26(5-6): p. 644-664.

79. Vergidis, K., C.J. Turner, and A. Tiwari, Business process perspectives: Theoretical developments vs. real-world practice. International Journal of Production Economics, 2008. 114(1): p. 91-104.

80. Ying, W. and S. Dayong, Multi-agent framework for third party logistics in E-commerce. Expert Systems with Applications, 2005. 29(2): p. 431-436.

81. Gengatharen, D.E. and C. Standing, A framework to assess the factors affecting success or failure of the implementation of government-supported regional e-marketplaces for SMEs. European Journal of Information Systems, 2005. 14(4): p. 417-433.

82. Otim, S. and V. Grover, An empirical study on Web-based services and customer loyalty. European Journal of Information Systems, 2006. 15(6): p. 527-542.

83. Seltsikas, P. and R.M. O'Keefe, Expectations and outcomes in electronic identity management: the role of trust and public value. European Journal of Information Systems, 2010. 19(1): p. 93-103.

84. Ranganathan, C. and C.V. Brown, ERP Investments and the Market Value of Firms: Toward an Understanding of Influential ERP Project Variables. Information Systems Research, 2006. 17(2): p. 145-161.

85. Jeyaraj, A., et al., Organizational and institutional determinants of B2C adoption under shifting environments. Journal of Information Technology, 2009. 24(3): p. 219-230.

86. Bharadwaj, S.S., K.B.C. Saxena, and M.D. Halemane, Building a successful relationship in business process outsourcing: an exploratory study. European Journal of Information Systems, 2010. 19(2): p. 168-180.

87. van Oosterhout, M., E. Waarts, and J. van Hillegersberg, Change factors requiring agility and implications for IT. European Journal of Information Systems, 2006. 15(2): p. 132-145.

88. Zhu, K., S. Dong, and K.L. Kraemer, Innovation diffusion in global contexts: determinants of post-adoption digital transformation of European companies. European Journal of Information Systems, 2006. 15(6): p. 601-617.

89. Hwang, Y., Investigating enterprise systems adoption: uncertainty avoidance, intrinsic motivation, and the technology acceptance model. European Journal of Information Systems, 2005. 14(2): p. 150-161.

90. Newman, M. and C. Westrup, Making ERPs work: accountants and the introduction of ERP systems. European Journal of Information Systems, 2005. 14(3): p. 258-272.

91. García-crespo, Á., et al., SEMO: a framework for customer social networks analysis based on semantics. Journal of Information Technology, 2010. 25(2): p. 178-188.

92. Bajwa, D.S., G. Pervan, and V.S. Lai, The adoption and use of collaboration information technologies: international comparisons. Journal of Information Technology, 2005. 20(2): p. 130-140.

93. Francalanci, C. and V. Morabito, IS integration and business performance: The mediation effect of organizational absorptive capacity in SMEs. Journal of Information Technology, 2008. 23(4): p. 297-312.

94. Zmud, R.W., K. Young-Gul, and L. Jae-Nam, Behavioral Intention Formation in Knowledge Sharing: Examining the Roles of Extrinsic Motivators, Social-Psychological Forces, and Organizational Climate. MIS Quarterly, 2005. 29(1): p. 87-111.

95. Gattiker, T.F. and D.L. Goodhue, What Happens After ERP Implementation: Understanding the Impact of Interdependence and Differentiation on Plant-Level Outcomes MIS Quarterly, 2005. 29(3): p. 559-585.

96. Song, M. and R.J. Thieme, A cross-national investigation of the R\&D-marketing interface in the product innovation process. Industrial Marketing Management, 2006. 35(3): p. 308-322.

97. Radhakrishnan, A., X. Zu, and V. Grover, A process-oriented perspective on differential business value creation by information technology: An empirical investigation. Omega, 2008. 36(6): p. 1105-1125.

98. Johnsen, T., et al., Centrality of customer and supplier interaction in innovation. Journal of Business Research, 2006. 59(6): p. 671-678.

99. O'Regan, N., A. Ghobadian, and M. Sims, Fast tracking innovation in manufacturing SMEs. Technovation, 2006. 26(2): p. 251-261.

100. Santos-Vijande, M.L. and L.I. Álvarez-González, Innovativeness and organizational innovation in total quality oriented firms: The moderating role of market turbulence. Technovation, 2007. 27(9): p. 514-532.

101. Raymond, L. and J. St-Pierre, $R \& D$ as a determinant of innovation in manufacturing SMEs: An attempt at empirical clarification. Technovation, 2010. 30(1): p. 48-56.

102. de Jong, J.P.J. and O. Marsili, The fruit flies of innovations: A taxonomy of innovative small firms. Research Policy, 2006. 35(2): p. 213-229.

103. Aragón-Correa, J.A., V.J. García-Morales, and E. Cordón-Pozo, Leadership and organizational learning's role on innovation and performance: Lessons from Spain. Industrial Marketing Management, 2007. 36(3): p. 349-359.

104. Stemberger, M.I., A. Manfreda, and A. Kovacic, Achieving top management support with business knowledge and role of IT/IS personnel. International Journal of Information Management, 2011. In Press, Corrected Proof. 
105. Chang, H.H. and I.C. Wang, Enterprise Information Portals in support of business process, design teams and collaborative commerce performance. International Journal of Information Management, 2011. 31(2): p. 171-182.

106. Sanders, N.R., An empirical study of the impact of e-business technologies on organizational collaboration and performance. Journal of Operations Management, 2007. 25(6): p. 1332-1347.

107. Grabski, S.V. and S.A. Leech, Complementary controls and ERP implementation success. International Journal of Accounting Information Systems, 2007. 8(1): p. 17-39.

108. Herzog, N.V., S. Tonchia, and A. Polajnar, Linkages between manufacturing strategy, benchmarking, performance measurement and business process reengineering. Computers \& Industrial Engineering, 2009. 57(3): p. 963-975.

109. Umapathy, K., S. Purao, and R.R. Barton, Designing enterprise integration solutions: effectively. European Journal of Information Systems, 2008. 17(5): p. 518-527.

110. Collins, J., W. Ketter, and M. Gini, Flexible decision support in dynamic inter-organisational networks. European Journal of Information Systems, 2010. 19(4): p. 436-448.

111. D'Aubeterre, F., R. Singh, and L. Iyer, Secure activity resource coordination: empirical evidence of enhanced security awareness in designing secure business processes. European Journal of Information Systems, 2008. 17(5): p. 528-542.

112. Koschmider, A., M. Song, and H.A. Reijers, Social software for business process modeling. Journal of Information Technology, 2010. 25(3): p. 308-322.

113. Galanakis, K., Innovation process. Make sense using systems thinking. Technovation, 2006. 26(11): p. 1222-1232.

114. Jiménez-Jiménez, D. and R. Sanz-Valle, Innovation, organizational learning, and performance. Journal of Business Research, 2011. 64(4): p. 408-417.

115. Vo, C.C., et al., Radio-Mama: An RFID based business process framework for asset management. Journal of Network and Computer Applications, 2011. 34(3): p. 990-997.

116. Jakkhupan, W., S. Arch-int, and Y. Li, Business process analysis and simulation for the RFID and EPCglobal Network enabled supply chain: A proof-of-concept approach. Journal of Network and Computer Applications, 2011. 34(3): p. 949-957.

117. Cheng, M.-Y., M.-H. Tsai, and Z.-W. Xiao, Construction management process reengineering: Organizational human resource planning for multiple projects. Automation in Construction, 2006. 15(6): p. 785-799.

118. Greasley, A., Using process mapping and business process simulation to support a process-based approach to change in a public sector organisation. Technovation, 2006. 26(1): p. 95-103.

119. Puschmann, T. and R. Alt, Developing an integration architecture for process portals. European Journal of Information Systems, 2005. 14(2): p. 121-134.

120. Berente, N., U. Gal, and Y. Yoo, Dressage, control, and enterprise systems: the case of NASA's Full Cost initiative. European Journal of Information Systems, 2010. 19(1): p. 21-34.

121. Bandara, W., G.G. Gable, and M. Rosemann, Factors and measures of business process modelling: model building through a multiple case study. European Journal of Information Systems, 2005. 14(4): p. 347-360.

122. Mantzana, V., et al., Identifying healthcare actors involved in the adoption of information systems. European Journal of Information Systems, 2007. 16(1): p. 91-102.

123. Sharif, A.M., Z. Irani, and P.E.D. Love, Integrating ERP using EAI: a model for post hoc evaluation. European Journal of Information Systems, 2005. 14(2): p. 162-174.

124. Lam, W., Investigating success factors in enterprise application integration: a case-driven analysis. European Journal of Information Systems, 2005. 14(2): p. 175-187.

125. Irani, Z., A.M. Sharif, and P.E.D. Love, Linking knowledge transformation to Information Systems evaluation. European Journal of Information Systems, 2005. 14(3): p. 213-228.

126. Thomas, D.M. and R.P. Bostrom, Team leader strategies for enabling collaboration technology adaptation: team technology knowledge to improve globally distributed systems development work. European Journal of Information Systems, 2010. 19(2): p. 223-237.

127. Daniel, E.M. and A. White, The future of inter-organisational system linkages: findings of an international Delphi study. European Journal of Information Systems, 2005. 14(2): p. 188-203.

128. Gosain, S., Z. Lee, and Y. Kim, The management of cross-functional inter-dependencies in ERP implementations: emergent coordination patterns. European Journal of Information Systems, 2005. 14(4): p. 371-387.

129. Recker, J., et al., The ontological deficiencies of process modeling in practice. European Journal of Information Systems, 2010. 19(5): p. 501-525.

130. Meissonier, R. and E. Houzé, Toward an 'IT Conflict-Resistance Theory': action research during IT preimplementation. European Journal of Information Systems, 2010. 19(5): p. 540-561.

131. Volkoff, O., D.M. Strong, and M.B. Elmes, Understanding enterprise systems-enabled integration. European Journal of Information Systems, 2005. 14(2): p. 110-120.

132. Holmqvist, M. and K. Pessi, Agility through scenario development and continuous implementation: a global aftermarket logistics case. European Journal of Information Systems, 2006. 15(2): p. 146-158.

133. Thiesse, F., J. Al-kassab, and E. Fleisch, Understanding the value of integrated RFID systems: a case study from apparel retail. European Journal of Information Systems, 2009. 18(6): p. 592-614.

134. Pelly Periasamy, K. and S.-K. Sia, Challenges in delivering cross-agency integrated e-services: The OBLS projectf. Journal of Information Technology, 2007. 22(4): p. 420-431.

135. Howard, M., Collaboration and the '3DayCar': a study of automotive ICT adoption. Journal of Information Technology, 2005. 20(4): p. 245-258.

136. Uwizeyemungu, S. and L. Raymond, Exploring an alternative method of evaluating the effects of ERP: a multiple case study. Journal of Information Technology, 2009. 24(3): p. 251-268.

137. Amrit, C. and J. Van Hillegersberg, Exploring the impact of socio-technical core-periphery structures in open source software development. Journal of Information Technology, 2010. 25(2): p. 216-229.

138. Shepherd, C., C. Clegg, and C. Stride, Opening the black box: A multi-method analysis of an enterprise resource planning implementation. Journal of Information Technology, 2009. 24(1): p. 81-102. 
139. Dong, L., D. Neufeld, and C. Higgins, Top management support of enterprise systems implementations. Journal of Information Technology, 2009. 24(1): p. 55-80.

140. Neville, K., C. Heavin, and E. Walsh, A case in customizing e-learning. Journal of Information Technology, 2005. 20(2): p. 117-129.

141. Lyytinen, K., M. Newman, and A.-r.A. Al-muharfi, Institutionalizing enterprise resource planning in the Saudi steel industry: A punctuated socio-technical analysis. Journal of Information Technology, 2009. 24(4): p. 286-304.

142. Ignatiadis, I. and J. Nandhakumar, The impact of enterprise systems on organizational resilience. Journal of Information Technology, 2007. 22(1): p. 36-36.

143. Garud, R. and A. Kumaraswamy, Vicious and Virtuous Circles in the Management of Knowledge: The Case of Infosys Technologies. MIS Quarterly, 2005. 29(1): p. 9-33.

144. Baloh, P., K. Uthicke, and G. Moon, A business process-oriented method of KM solution design: A case study of Samsung Electronics. International Journal of Information Management, 2008. 28(5): p. 433-437.

145. McAdam, R., et al., Defining and improving technology transfer business and management processes in university innovation centres. Technovation, 2005. 25(12): p. 1418-1429.

146. Calia, R.C., F.M. Guerrini, and G.L. Moura, Innovation networks: From technological development to business model reconfiguration. Technovation, 2007. 27(8): p. 426-432.

147. Aversano, L., et al., Technology-driven business evolution. Journal of Systems and Software, 2006. 79(3): p. 314338.

148. Tarafdar, M. and S.R. Gordon, Understanding the influence of information systems competencies on process innovation: A resource-based view. The Journal of Strategic Information Systems, 2007. 16(4): p. 353-392.

149. Grefen, P., et al., Dynamic business network process management in instant virtual enterprises. Computers in Industry, 2009. 60(2): p. 86-103.

150. Huang, Z., X. Lu, and H. Duan, Mining association rules to support resource allocation in business process management. Expert Systems with Applications, 2011. In Press, Corrected Proof.

151. Trkman, P., The critical success factors of business process management. International Journal of Information Management, 2010. 30(2): p. 125-134.

152. Tarantilis, C.D., C.T. Kiranoudis, and N.D. Theodorakopoulos, A Web-based ERP system for business services and supply chain management: Application to real-world process scheduling. European Journal of Operational Research, 2008. 187(3): p. 1310-1326.

153. Glassey, O., A case study on process modelling -- Three questions and three techniques. Decision Support Systems, 2008. 44(4): p. 842-853.

154. Zhang, Z., et al., A framework of ERP systems implementation success in China: An empirical study. International Journal of Production Economics, 2005. 98(1): p. 56-80.

155. Cheng, M.-Y., M.-H. Tsai, and W. Sutan, Benchmarking-based process reengineering for construction management. Automation in Construction, 2009. 18(5): p. 605-623.

156. Goel, S. and V. Chen, Can business process reengineering lead to security vulnerabilities: Analyzing the reengineered process. International Journal of Production Economics, 2008. 115(1): p. 104-112.

157. Tzeng, S.-F., W.-H. Chen, and F.-Y. Pai, Evaluating the business value of RFID: Evidence from five case studies. International Journal of Production Economics, 2008. 112(2): p. 601-613.

158. Chouinard, M., S. D'Amours, and D. Aï-Kadi, Integration of reverse logistics activities within a supply chain information system. Computers in Industry, 2005. 56(1): p. 105-124.

159. Indihar Stemberger, M. and J. Jaklic, Towards E-government by business process change--A methodology for public sector. International Journal of Information Management, 2007. 27(4): p. 221-232.

160. Klaus, T., S.C. Wingreen, and J.E. Blanton, Resistant groups in enterprise system implementations: a Qmethodology examination. Journal of Information Technology, 2010. 25(1): p. 91-106.

161. Toh, K.T.K., P. Nagel, and R. Oakden, A business and ICT architecture for a logistics city. International Journal of Production Economics, 2009. 122(1): p. 216-228.

162. Martinsson, F., Agile improvement practices in software organizations. European Journal of Information Systems, 2006. 15(2): p. 169-182.

163. Salmela, H., Analysing business losses caused by information systems risk: a business process analysis approach. Journal of Information Technology, 2008. 23(3): p. 185-202.

164. Wastell, D.G., T. McMaster, and P. Kawalek, The rise of the phoenix: methodological innovation as a discourse of renewal. Journal of Information Technology, 2007. 22(1): p. 59-59.

165. Piccoli, G. and B. Ives, Review: IT-Dependent Strategic Initiatives and Sustained Competitive Advantage: A Review and Synthesis of the Literature. MIS Quarterly, 2005. 29(4): p. 747-776. 


\section{Appendices}

6.1 Appendix 1: Classification based on approaches with references

\begin{tabular}{|c|c|c|c|c|}
\hline Approaches & $\begin{array}{c}\text { AIS } \\
\text { Journals }\end{array}$ & References & $\begin{array}{c}\text { Science } \\
\text { Direct }\end{array}$ & References \\
\hline Conceptual & 4 & {$[58],[59],[60],[61]$} & 13 & $\begin{array}{l}{[62],[63],[64],[65],[66],[67],} \\
{[68],[69],[70],[71],[72],[73],} \\
{[74]}\end{array}$ \\
\hline Review & 3 & [75], [76], [77] & 4 & {$[63],[78],[79],[80]$} \\
\hline Data Analysis & 5 & {$[81],[82],[83],[84],[85]$} & 1 & {$[71]$} \\
\hline Survey & 11 & $\begin{array}{l}\text { [86], [87], [88], [89], [90], [61], [91], } \\
{[92],[93],[94],[95]}\end{array}$ & 16 & $\begin{array}{l}\text { [96], [97], [98], [99], [100], [65], } \\
{[101],[102],[67],[103],[104],} \\
{[105],[106],[79],[107],[108]}\end{array}$ \\
\hline Experiment & 4 & [109], [110], [111], [112] & 10 & $\begin{array}{l}\text { [113], [114], [20], [115], [15], [71], } \\
{[116],[117],[24],[118]}\end{array}$ \\
\hline Case Study & 30 & $\begin{array}{l}{[81],[119],[120],[121],[122],[123],} \\
{[124],[125],[126],[127],[128],[129],} \\
{[130],[131],[132],[87],[83],[59],} \\
{[90],[133],[134],[135],[136],[137],} \\
{[138],[139],[140],[141],[142],[143]}\end{array}$ & 27 & $\begin{array}{l}{[144],[96],[62],[145],[146],} \\
{[147],[148],[68],[149],[17],} \\
{[150],[19],[151],[71],[152],} \\
{[153],[154],[155],[22],[23],} \\
{[156],[72],[73],[157],[158],} \\
{[159],[118]}\end{array}$ \\
\hline Developmental & 1 & [160] & 9 & $\begin{array}{l}{[114],[69],[70],[149],[18],[19],} \\
{[161],[155],[21]}\end{array}$ \\
\hline $\begin{array}{l}\text { Others } \\
\text { (Ethnography, } \\
\text { Action Research) }\end{array}$ & 5 & [119], [130], [162], [163], [164] & - & - \\
\hline Total* & 63 & & 80 & \\
\hline
\end{tabular}

6.2 Appendix 2: Business process components with references

\begin{tabular}{|c|c|c|c|}
\hline & & \multicolumn{2}{|c|}{ References } \\
\hline Covered Topics & Total & AIS top basket of journals & Science Direct \\
\hline $\begin{array}{l}\text { Customer } \\
\text { Management }\end{array}$ & $7 / 9$ & [82], [132], [83], [133], [134], [91], [140] & $\begin{array}{l}\text { [98], [146], [101], [149], [19],[79], [72], [80], } \\
{[118]}\end{array}$ \\
\hline Planning & $12 / 14$ & $\begin{array}{l}{[82],[123],[124],[132],[87],[83],[133],[84],} \\
{[134],[139],[141],[95]}\end{array}$ & $\begin{array}{l}{[96],[98],[64],[99],[146],[113],[101],} \\
{[149],[17],[115],[161],[22],[23],[159]}\end{array}$ \\
\hline Control & $14 / 13$ & $\begin{array}{l}{[119],[120],[110],[128],[131],[162],[58],} \\
{[75],[61],[163],[136],[142],[165],[95]}\end{array}$ & $\begin{array}{l}{[97],[145],[147],[70],[17],[150],[15],} \\
{[18],[154],[107],[21],[158],[80]}\end{array}$ \\
\hline $\begin{array}{l}\text { Resource } \\
\text { Management }\end{array}$ & $8 / 10$ & {$[86],[110],[90],[75],[60],[141],[142],[165]$} & $\begin{array}{l}{[63],[66],[150],[115],[15],[152],[161],} \\
{[22],[23],[117],}\end{array}$ \\
\hline $\begin{array}{l}\text { Knowledge } \\
\text { Management }\end{array}$ & $21 / 18$ & $\begin{array}{l}\text { [81], [109], [119], [123], [125], [111], [127], } \\
{[128],[129],[59],[88],[89],[75],[84],[138],} \\
{[85],[112],[93],[164],[94],[143]}\end{array}$ & $\begin{array}{l}{[144],[62],[145],[64],[114],[100],[78],} \\
{[65],[148],[68],[69],[105],[71], \|[153],} \\
{[79],[156],[157],[24]}\end{array}$ \\
\hline Change & $15 / 17$ & {$[86],[120],[121],[127],[130],[131],[162]$} & {$[146],[113],[114],[65],[148],[17]$} \\
\hline Process & & [58], [87], [133], [61], [134], [135], [136], [164] & $\begin{array}{l}{[20],[155],[22],[156],[73],[157],[158],} \\
{[80],[159],[118],[74]}\end{array}$ \\
\hline Learning & $8 / 12$ & [109], [125], [133], [137], [76], [93], [92], [143] & $\begin{array}{l}{[62],[145],[63],[146],[65],[101],[102],} \\
{[67],[148],[103], \mid[116],[118]}\end{array}$ \\
\hline People & $12 / 5$ & $\begin{array}{l}\text { [120], [121], [126], [130], [89], [61], [160], } \\
{[139],[93],[164],[94],[143]}\end{array}$ & {$[63],[99],[104],[151],[154]$} \\
\hline $\begin{array}{l}\text { Performance } \\
\text { Management }\end{array}$ & $11 / 17$ & $\begin{array}{l}{[121],[122],[124],[125],[126],[129],[131],} \\
{[90],[133],[93],[165]}\end{array}$ & $\begin{array}{l}\text { [96], [97], [99], [114], [66], [147], [67], } \\
{[148],[103],[104],[151],[106],[22],[117],} \\
{[72],[21],[108]}\end{array}$ \\
\hline
\end{tabular}


6.3 Appendix 3: Classification based on the application area with references

\begin{tabular}{|c|c|c|c|c|}
\hline & AIS & & Science & \\
\hline Application areas & Journals & References & Direct & References \\
\hline Banking/Financial & 8 & $\begin{array}{l}\text { [124], [128], [87], [59], [90], [84], } \\
{[163],[85]}\end{array}$ & 4 & [19], [151], [79], [107] \\
\hline Healthcare & 3 & {$[122],[128],[85]$} & 6 & {$[62],[98],[148],[150],[15],[157]$} \\
\hline Government & 8 & $\begin{array}{l}{[81],[120],[121],[128],[83],[59],} \\
{[134],[164]}\end{array}$ & 5 & [64], [147], [73], [159], [118] \\
\hline Logistics & 3 & {$[121],[87],[59]$} & 3 & {$[104],[161],[80]$} \\
\hline Supple Chain & 2 & {$[132],[61]$} & 6 & [149],[22], [116], [23], [158], [80] \\
\hline IT & 10 & $\begin{array}{l}{[121],[123],[130],[162],[87],[59],} \\
{[137],[91],[85],[94]}\end{array}$ & 1 & {$[144]$} \\
\hline Manufacturing & 8 & $\begin{array}{l}{[125],[128],[131],[59],[88],[136],} \\
{[141],[95]}\end{array}$ & 14 & $\begin{array}{l}{[99],[146],[78],[65],[66],[101],} \\
{[102],[103],[68],[104],[152],} \\
{[154],[106],[108]}\end{array}$ \\
\hline Paper Industry & 1 & {$[163]$} & - & - \\
\hline Automotive & 2 & [119], [135] & 3 & [104], [149], [105] \\
\hline Education & 2 & {$[139],[140]$} & 2 & {$[145],[79]$} \\
\hline Retail & 6 & [59], [109], [88], [133], [82], [85] & 1 & [104] \\
\hline Others & 20 & $\begin{array}{l}{[86],[110],[111],[126],[127],[129],} \\
{[58],[59],[89],[75],[60],[138],[76],} \\
{[85],[160],[112],[93],[92],[142],} \\
{[165]}\end{array}$ & 25 & $\begin{array}{l}\text { [96], [97], [63], [113], [114], [100], } \\
\text { [67], [103], [68], [104], [69], [70], } \\
{[17],[20],[115],[18],[71],[155],} \\
{[79],[156],[117],[72],[21],[24],} \\
{[74]}\end{array}$ \\
\hline Total* & 73 & & 70 & \\
\hline
\end{tabular}

